\title{
Analysis of a Large Company's Global Activity Sustained by the Organizational Culture
}

\author{
Alexandru Trifu \\ University Petre Andrei of Iasi, Romania \\ alexandru.trifu@gmail.com
}

\begin{abstract}
Organization's strategic position has to be understood in relation to the external environment, its internal resources, the employees' skills, desires, and influences endogenous and exogenous. But, above all, the competition and the programs applied have to be different from that activities or services of the competitors. Market research provides the firm with information regarding the markets or market segments with the best prospects, the price levels accepted by the market, the ways of distributing the products on the market, promotional actions, etc. Equally important for grounding the strategy are the macroeconomic forecasts, the field projections, and the policies of the bodies regulating and supervising insurances. This provides the guidance of the organization's development in accordance with the main macroeconomic developments foreshadowed for the following period. The quality of the global activity is given by the nature of the organizational culture, a powerful instrument for performing the management and getting the appropriate results. I think that Petrom is the most suitable enterprise (firm) for the analyze, being the largest company in Southeast Europe, whose market penetration force and market sustainability are largely due to the European management implemented by OMV, as Petrom is part of the OMV structure. At the same, in this period, it is capable to get down the prices, in order to keep the clients, but maintaining the efficiency of the main activity.
\end{abstract}

Keywords: Competition, development, efficiency, organization culture, environmental impulses, goodwill

\section{Introduction}

The general approach of the problem: Being aware of the fact that competition plays a decisive role in marketing planning, Petrom needs to constantly compare its products, prices, distribution channels, and promotion actions with those of the competitors. This way the company will be able to identify its advantages and disadvantages when fighting competition and, thus, will be able to launch more accurate attacks on the competition and to have a better defense over its attacks. In the market economy, competition is an objective necessity, being part of the market "game rules". Its activity stimulates the concerns for growing, diversifying and qualitatively improving the supply of goods, and for adapting it to the dynamic of the requirements. At the same time, the competition mechanism ensures placing the prices at their actual quotes, favoring cost rationalization as a means of increasing profit.

\section{The activity and the main features of PETROM Company}

Petrom is the largest Romanian oil and gas company, which activates in the following sectors: Pitting \& Production, Refining \& Petrochemicals, Natural Gas and Marketing. Petrom mines estimated oil and gas reserves of 1 billion barrels of oil equivalent (boe), has an annual refining capacity of 8 million tons and 593 filling stations in Romania. The company also owns an international network of 211 filling stations located in Moldova, Bulgaria and Serbia. Petrom, a member of OMV Group, is the largest oil and gas producer in Southeast Europe. Petrom's business segments are Pitting \& Production, Gas \& Energy and Refining \& Marketing. The main achievements regarding the Pitting \& Production segment in 2011 were:

- Average annual output of over 173,700 boe/day achieved in Romania

- $\quad$ Reserve replacement rate in Romania maintained at 70\% for the fourth consecutive year

- $\quad$ Production costs in Romania fell 1\% in USD and 5\% in RON compared to 2010.

The success of the entire enterprise, is given also, to organizational culture, mainly to the goodwill instrument. Why? Because the organizational culture is considered by Lorek beliefs shared by an organization's managers about how they will organize their business with the employees (in their mutual interest); or, the Mintzberg definition regards this instruments of improving the entire company behavior and activity as traditions and beliefs of an organization by which it is distinguished from other 
organizations and to instill safety and durability in an organization ${ }^{1}$. Currently speaking, the word "goodwill" express favorable attitudes towards enterprise market. Goodwill, generally speaking, represents a company's ability to achieve over-profit being translated into additional profit obtained from the enterprise that has good reputation in dealing with other traders' 2 , which operates in a wider open market. Source goodwill is represented by the intangible elements of the enterprise (firm). Intangible elements are non-material elements that may or may not be registered in the patrimony (i. e. the recorded intangible assets), but which contributes to maintain current potential and influence the company's financial results and enterprise value. Herewith, we may see the most important situations and figures regarding the solidity of the company, its profitability and solvency:

Table 1: Solidity, profitability and solvency of the company

\begin{tabular}{|c|c|c|c|c|}
\hline & & 2010 & 2011 & $\Delta(\%)$ \\
\hline Sales revenues & & 18,616 & 22,614 & 21 \\
\hline EBIT (Earnings before interest and tax) & & 2,986 & 4,936 & 65 \\
\hline Net profit & & 2,190 & 3,759 & 72 \\
\hline $\begin{array}{l}\text { Net profit attributable to the shareholders } \\
\text { company }\end{array}$ & f the mother & 2,201 & 3,757 & 71 \\
\hline $\begin{array}{l}\text { Mining activity cash flows } \\
\text { Investment }\end{array}$ & & $\begin{array}{l}4,630 \\
4,863\end{array}$ & $\begin{array}{l}6,442 \\
4,803\end{array}$ & $\begin{array}{l}39 \\
(1)\end{array}$ \\
\hline Number of employees at the end of the period & & 24,662 & 22,912 & (7) \\
\hline & & 2009 & 2010 & 2011 \\
\hline Total production of hydrocarbons (billion boe) & & 68.29 & 67.08 & 67.77 \\
\hline Refinery capacity utilization (\%) & & 65 & 49 & 79 \\
\hline Total sales of refined products (billion tones) & & 6.18 & 5.47 & 5.23 \\
\hline Number of distribution stations & & 814 & 801 & 793 \\
\hline Number of employees at the end of the period & & 28,984 & 24,662 & 22,912 \\
\hline Indicators & 2009 & 2010 & & 2011 \\
\hline Net profit, billion lei & 1,368 & 1,799 & & 3,686 \\
\hline Net turnover, billion lei & 12,842 & 13,953 & & 16,565 \\
\hline Operating result, billion lei & 1,197 & 3,202 & & 5,034 \\
\hline $\begin{array}{l}\text { Operational expenditures, mil lei } \\
\text { Liquidity }\end{array}$ & 12,009 & 11,428 & & 11,998 \\
\hline (cash and cash equivalent), billion lei & 280 & 1,416 & & 567 \\
\hline
\end{tabular}

\section{Conclusion}

Petrom is the largest integrated operator in the oil sector in Romania and South Eastern Europe; it performs mining activities, as well as oil and gas production activities, refining and petrochemical activities, and commercializes fuels and complementary products. Its experience in the field, accumulated during 150 years, turns Petrom into a leader of the Romanian economy, by combining the tradition of the oil industry with the modern organization of an integrated company. Being part of the OMV group, Petrom benefits from the transfer of know-how from the Austrian company, which leads, among other things, to an increased quality of the products and services provided and, therefore, of the way it is perceived by the consumers. The increased fuel sales are also due to the competitive advantages that Petrom has against the Romanian competitors. Of these, the following may be mentioned:

\footnotetext{
${ }^{1}$ Hickson, D.J., Pugh, D.S. The organizations' management-a synthesis of the most important works in the field. Ed. Codecs, Bucuresti, 2004, pg. 113.

${ }^{2}$ Deaconu, Alecxandrina Evaluarea afacerii (Business evaluation), Ed. Intelcredo, Cluj-Napoca, 2002, p. 87
} 
- The membership of OMV has the effect of the transfer of know-how from the Austrian company, which leads, among other things, to an increased quality of the products and services provided and, therefore, of the way it is perceived by the consumers.

- Improved marketing department;

- The fact that Petrom is well known both at national and international level;

- The fact that Petrom launches and improves its products every year, at better prices than its competitors.

Petrom's reputation contributes to the perception of quality, as it is considered to be a standard of quality, based on an outstanding organizational culture, both from Romanian and Austrian parts. And, last but not least, the company image has increased market share. Even when the competing offers were similar, buyers reacted differently thanks to Petrom's image, which represents the guarantee of an offer which is customer oriented. It has been proved once again that a wisely elaborated policy brings along benefits both to consumers and producers. With increasing competition, company reputation and market share can be maintained or improved only by permanently adapting to the new conditions and by accepting the challenges that arise, that means the commitment to becoming more and more performing and to achieving excellence in business. In order to improve its image, it would be useful for Petrom to support the ecological activities of the national economy, which can create for the Romanian customers the image of a company that is concerned about the environment. Considering the general context of scarce natural resources, a medium and long term strategy needs to be developed regarding Petrom's capacity to face the energy challenges caused by the incumbent oil crisis, which will affect all the oil companies in the world. In this respect, it is necessary to create departments for the research and development of new technologies and products and to use the oil and gas resources in a rational manner, as well as to gradually replace them. In order to provide for the sale of its finished goods, Petrom must consider providing best quality services to final customers through both its distribution stations and its deposits (wholesale sales). Consumer satisfaction is reflected by the increased oil product sales incomes, particularly fuel sales incomes. The income of the distribution stations should be optimized by adding to the income from the fuel sales the income resulting from the sale of complementary products, as a result of modernizing the distribution network and diversifying the range of products. Each distribution branch needs to be allocated a minimum level of income that has to be earned from the sale of complementary products.

Improving the activity involves earning high incomes, in the conditions of low costs, by maintaining or even improving the quality of the products and services. This means, among other things, increasing labor productivity and reducing the operating costs from the activities of transportation and distribution of oil products. Improving the quality / price ratio should be a constant concern of Petrom, as it leads to customer loyalty and helps gaining the customers of other companies. Petrom has reached positive financial results during the recent years, which will help achieve the company's strategic objectives. Thanks to the capital infusion, Petrom is ready for corporate development. The investment program for 2011, whose total value amounts to over 3 billion Euros, supports the achievement of the development objectives assumed for each segment of activity. The improved performance and improved cost position in all business segments of activity will ensure the sustainable profitability of the company; the process of modernization initiated in 2005, the new technologies, the expertise and know-how of OMV and the necessary capital for investments form Petrom's way towards success. On the other hand, Organizational culture is practically invisible force behind a company's tangible things. Energy generated by organizational culture should be directed towards achieving company objectives. Goodwill is actually an overstatement in obtaining the over-profit of the enterprise. This results from business intangibles. The whole PETROM system has become a dynamic, successful, responsible European company and the slogan "the core of movement" is the company's guarantee to act to the benefit of the society and of its clients. The fact is that the company worth more than the sum of its components. 


\begin{abstract}
STRENGTHS
The entire oil production of the country is extracted and processed by Petrom;

The existence of a large production, refinery and storage capacity for oil and oil products;

A powerful petrochemical district, integrated with the refinery;

Direct pipeline connections between the two major refineries (Petrobrazi and Arpechim) and the nearby refineries;

Flexibility in processing various types of oil (indigenous and imported);

Quality products, which are in accordance with high standards;

Wide range of products
\end{abstract}

\section{OPPORTUNITIES}

The only company that has discovered oil reserves;

The modernization and retehnologization of the refineries, which reduces the production costs;

It has a well developed infrastructure compared to many companies in Central and Eastern Europe

\section{WEAKNESSES}

The reduction of oil production during the last four years

The mining of less than $50 \%$ of the refineries' production capacity;

Large refinery costs;

The existence of outdated production capacities;

Outdated transportation capacity (pipelines).

\section{THREATS}

Lack of the necessary funds to invest in modern technologies;

Lack of liquidity in the economy;

Increased imports of oil.

Table 3: Commercial Sector Analysis

\section{STRENGTHS}

An effective marketing department;

Petrom is well known both internally and internationally;

Leader on the oil products market;

Launches or improves its products every year.

\section{OPPORTUNITIES}

Of reinforcing the company-customer Rapid development of other operators.

relationship;

Of increasing market share;

Of penetrating new foreign distribution

markets.

\section{WEAKNESS}

High production costs, while the distribution prices are among the lowest on the internal market

\section{THREATS}

Table 4: Financial Analysis

\begin{tabular}{|c|c|}
\hline STRENGTHS & WEAKNESSES \\
\hline $\begin{array}{l}\text { Economically favorable evolution, especially } \\
\text { during recent years because of the } \\
\text { reorganizations that took place; }\end{array}$ & $\begin{array}{l}\text { Stock assessment indicators are less } \\
\text { favorable compared to other oil companies } \\
\text { in the region. }\end{array}$ \\
\hline
\end{tabular}

The existence of self-financing capacities;

The existence of debt carrying capacities;

Has the liquidity needed to cover short term debt?

\section{OPPORTUNITIES}

Investment opportunities;

Development of external activities.

\section{THREATS}

Low purchasing power;

High taxation. 


\section{References}

Deaconu, A. (2002). Evaluarea afacerii (Business evaluation), Editura Intelcredo, Cluj-Napoca.

Hickson, D. J. \& Pugh, D. S. (2004). Managementul organizațiilor - o sinteza a celor mai importante lucrări in domeniu (The organizations' management-a synthesis of the most important works in the field), Ed. Codecs, București.

***- ProspectSPOPetrom, section one, 2011.

S.C. PETROM S.A. - Petrom's objectives by the year 2010.

www.petrom.ro

www.lukoil.ro

www.omv.ro

www.rompetrol.ro

www.agip.ro 